\title{
Shrubs as ecosystem engineers in a coastal dune: influences on plant populations, communities and ecosystems
}

\author{
J. Hall Cushman, Jeffrey C. Waller \& Derek R. Hoak
}

\begin{abstract}
Question: How do two shrubs with contrasting lifehistory characteristics influence abundance of dominant plant taxa, species richness and aboveground biomass of grasses and forbs, litter accumulation, nitrogen pools and mineralization rates? How are these shrubs - and thus their effects on populations, communities and ecosystems - distributed spatially across the landscape?

Location: Coastal hind-dune system, Bodega Head, northern California.

Methods: In each of 4 years, we compared vegetation, leaf litter and soil nitrogen under canopies of two native shrubs - Ericameria ericoides and the nitrogen-fixing Lupinus chamissonis - with those in adjacent open dunes.
\end{abstract}

Results: At the population level, density and cover of the native forb Claytonia perfoliata and the exotic grass Bromus diandrus were higher under shrubs than in shrub-free areas, whereas they were lower under shrubs for the exotic grass Vulpia bromoides. In contrast, cover of three native moss species was highest under Ericameria and equally low under Lupinus and shrub-free areas. At community level, species richness and aboveground biomass of herbaceous dicots was lower beneath shrubs, whereas no pattern emerged for grasses. At ecosystem level, areas beneath shrubs accumulated more leaf litter and had larger pools of soil ammonium and nitrate. Rates of nitrate mineralization were higher under Lupinus, followed by Ericameria and then open dune. At landscape level, the two shrubs - and their distinctive vegetation and soils - frequently had uniform spatial distributions, and the distance separating neighbouring shrubs increased as their combined sizes increased.

Conclusions: Collectively, these data suggest that both shrubs serve as ecosystem engineers in this coastal dune, having influences at multiple levels of

Cushman, J.H. (corresponding author, cushman@ sonoma.edu), Waller, J.C. (betweenpacifictides@ gmail.com) \& Hoak, D.R. (derek.hoak@leusd.k12. ca.us): Department of Biology, Sonoma State University, Rohnert Park, California 94928, USA. biological organization. Our data also suggest that intraspecific competition influenced the spatial distributions of these shrubs and thus altered the distribution of their effects throughout the landscape.

Keywords: Ecosystem engineers; Litter accumulation; Nitrogen pools and mineralization rates; Spatial patterns; Species richness and biomass production.

Nomenclature: Hickman (1993).

\section{Introduction}

Species that have large impacts on the distribution, amount and composition of resources in the environment - either through their own physical structures or the artifacts they create - are increasingly recognized as ecosystem engineers (Jones et al. 1994, 1997). The non-trophic impacts of such taxa can alter population, community and ecosystem characteristics through creation, modification or maintenance of habitats in the environment (Wright $\&$ Jones 2004). The activities of ecosystem engineers lead to considerable spatial heterogeneity, creating distinct mosaics of engineered and unmodified patches throughout landscapes (Badano et al. 2006; Wright et al. 2006; Shachak et al. 2008). As reviewed extensively by Jones et al. (1994), ecosystem engineers are a taxonomically diverse group, with representatives including vertebrates, invertebrates, algae, nonvascular plants and higher plants (especially woody species).

Shrubs are dominant features of many landscapes throughout the world, and can play key roles as ecosystem engineers by altering the physical environment beneath their canopies as well as the characteristics of plant populations, communities and ecosystems (Hunter \& Aarssen 1988; Callaway 1995; Scholes \& Archer 1997; Wright et al. 2006; Shachak et al. 2008). Especially in more open and arid landscapes, shrubs can alter water and light availability beneath their canopies as well as create "islands of fertility" (i.e. patches of increased nitrogen availability), often through the deposition of leaf litter and by trapping wind-blown litter from the 
surrounding area (Callaway 1995; Alpert \& Mooney 1996; Pugnaire et al. 1996; Scholes \& Archer 1997; Shumway 2000; Flores \& Jurado 2003; Pugnaire et al. 2004; Uesaka \& Tsuyuzaki 2004; Wright et al. 2006; Shachak et al. 2008).

The environmental modifications caused by shrubs can, in turn, lead to a wide range of effects on herbaceous and woody plant species growing beneath their canopies. At the individual and population level, shrubs can have positive effects on understorey species (i.e. facilitation) by creating favourable sites for seed accumulation, germination, growth and reproduction (Day \& Wright 1989; Callaway 1992, 1995; Aguiar \& Sala 1994; Shumway 2000; Tirado \& Pugnaire 2003; Armas \& Pugnaire 2005; Holzapfel et al. 2006), or by protecting them from herbivores (Bartholemew 1970; Jaksic \& Fuentes 1980; McAuliffe 1986; Hamback et al. 2000). In contrast, they can have negative effects on understorey species by creating unfavourable conditions via competition (Mahall et al. 1981; Callaway et al. 1991; Pugnaire et al. 1996) or deposition of allelopathic compounds in the soil (Muller \& del Moral 1966; Rice 1984; Williamson 1990). Such positive and negative effects often occur simultaneously, and the net result often varies greatly in space and time, depending on life-history stages and the severity of abiotic conditions (Callaway \& Walker 1997; Armas \& Pugnaire 2005). At the community level, shrubs can alter the composition, species richness and productivity of understorey plant assemblages (Scholes \& Archer 1997; Pugnaire et al. 2004; Holzapfel et al. 2006; King 2008; Agra \& Ne'eman 2009).

The influence of shrubs on the landscapes they inhabit should vary greatly with the life-history characteristics of resident plant species in the system, including those of the shrubs themselves. Although very little work has been done in this area, considerable insight will be gained by exploring the degree to which multiple shrub species in the same system - that differ markedly in ecological characteristics - vary in their impacts on population, community and ecosystem-level characteristics. Similarly, resident plant groups with different suites of life-history characteristics - such as grasses and herbaceous dicots (forbs) - should also vary in response to shrubs.

In a coastal dune site in northern California, we explored the importance of shrubs as ecosystem engineers at the population, community and ecosystem levels by focusing on two common native shrubs - Ericameria ericoides (Asteraceace) and the nitrogen-fixing Lupinus chamissonis (Fabaceace) - and addressed the following questions. First, how do the understorey environments of these two shrub species differ from each other and from the adjacent shrub-free dune with respect to (a) percent cover and density of three dominant herbaceous plant species and a complex of moss species, (b) species richness and aboveground biomass of both grasses and forbs, (c) litter accumulation, and (d) ammonium and nitrate pools and mineralization rates? Second, how are these two shrub species - and thus their effects on the population, community and ecosystem distributed spatially in the landscape? Answers to these questions will provide valuable insight concerning the degree to which two shrub species with contrasting characteristics have influences at multiple levels of biological organization.

\section{Study system}

This study was conducted during the winter and spring of 1996, 1997, 1998 and 2000 in a coastal hinddune system on Bodega Head, a small peninsula in Sonoma County, California, approximately $105 \mathrm{~km}$ north of San Francisco. The $300 \times 500 \mathrm{~m}$ study area consists of two adjacent dune ridges and the associated trough between them, which are located within Sonoma Coast State Beaches, adjacent to the University of California Bodega Marine Reserve. This region is characterized by a Mediterranean-type climate, with $90 \%$ of annual precipitation occurring between October and April (Barbour et al. 1973). The sandy top soils of this dune system contain very little organic matter and are fast-draining and nitrogenpoor (Barbour et al. 1973; McNeil \& Cushman 2005; Lortie \& Cushman 2007).

The two most abundant shrub species in this system are Lupinus chamissonis (Fabacaeae; hereafter referred to by its genus name) and Ericameria ericoides (Asteraceae; hereafter referred to by its genus name), having $15 \%$ and $20 \%$ cover, respectively (Warner \& Cushman 2002; McNeil \& Cushman 2005; Huntzinger et al. 2008). Both species are low-growing evergreen shrubs native to the coastal dunes of California. Lupinus is a fastgrowing, nitrogen-fixing shrub with large compound leaves and a lifespan ranging from 2 to 10 years. Its size is variable, depending on environmental conditions, but typically ranges from $0.5 \mathrm{~m}$ to $1.0 \mathrm{~m}$ in height at our site. In contrast, Ericameria is slow-growing and extremely long-lived, with small, dense leaves that are retained longer than in Lupinus. It ranges from $0.25 \mathrm{~m}$ to $0.50 \mathrm{~m}$ in height and spreads laterally more than Lupinus, typically 
reaching up to $2 \mathrm{~m}$ in diameter. Waller (1998) reported that the microenvironments beneath the canopies of these two shrub species did not differ significantly from each other in terms of ambient light, air temperature and soil moisture levels.

A wide variety of native and exotic herbaceous plant species inhabit our dune site. Three species are especially abundant: the native annual forb Claytonia perfoliata (Portulacaceae) and the exotic annual grasses Bromus diandrus (Poaceae) and Vulpia bromoides (Poaceae). Three native moss species are also quite common: Syntrichia ruralis ( = Tortula ruralis; Pottiaceae), Didymodon vinealis (Pottiaceae) and Homalothecium arenarium (Brachytheciaceae).

\section{Methods}

\section{Study design}

To evaluate how vegetation and soil characteristics vary among three common microhabitat types at our study site, in each of 4 years we sampled under the canopies of Lupinus and Ericameria and in shrub-free areas. In 1996 and 1997, we established 24 blocks throughout the site, each consisting of a pair of Lupinus and Ericameria individuals and an adjacent shrub-free zone. We sampled a different set of 17 blocks in 1998, and 14 blocks in 2000. We used blocks to control for the substantial spatial variation in soil characteristics that exist at our site (see Lortie \& Cushman 2007). In all years, we matched shrubs within a block for size and separated them from each other and any adjacent shrubs by $2 \mathrm{~m}$. We randomly selected each associated shrub-free area of dune, which consisted of a $1-\mathrm{m}$ circular plot within $2 \mathrm{~m}$ of both shrubs. All three microhabitat types in a block were matched for slope and aspect.

\section{Density and cover of individual plant species}

In March 1996, we determined the density and percent cover of three plant species that were especially abundant in the three microhabitat types (i.e. under Lupinus, under Ericameria and in shrub-free patches). We randomly located a $0.03-\mathrm{m}^{2}$ sampling ring in each microhabitat type ( 24 blocks, see above) and counted the number of individual Claytonia, Bromus and Vulpia plants within it and visually estimated percentage cover of these taxa.

At the same time, we also established a $625-\mathrm{m}^{2}$ plot at the site and quantified percent cover of three common moss species (Syntrichia, Didymodon and Homalothecium) in the three microhabitat types.
Using the $0.03-\mathrm{m}^{2}$ sampling ring discussed above, we visually estimated percentage cover of moss under all Lupinus $(n=16)$ and Ericameria $(n=29)$ canopies in the plot, as well as in randomly selected shrub-free areas $(n=30)$. We pooled cover data for all three moss species because they commonly cooccur in complex mixtures.

\section{Plant species richness and aboveground biomass}

In April and May 1998 and 2000, we determined the species richness of grasses and forbs within the three microhabitats. We randomly placed a $0.05-\mathrm{m}^{2}$ sampling ring in three non-overlapping areas beneath the canopy of each shrub and shrub-free area. Within each ring, we recorded the presence of all vascular plant species and pooled these data for the three samples taken from each microhabitat type in a block. In 2000, we also harvested all aboveground biomass contained within the three sampling rings. We then sorted all harvested biomass to species, dried this material for $48 \mathrm{~h}$ at $60^{\circ} \mathrm{C}$, and weighed it.

\section{Litter biomass and soil nitrogen}

In March 1996, we quantified litter accumulation in each of the three microhabitat types. We removed all plant litter from a randomly selected 75$\mathrm{cm}^{2}$ area of soil surface, sieved the samples to remove soil particles (1-mm mesh size), and dried the remaining material for $48 \mathrm{~h}$ at $60^{\circ} \mathrm{C}$ before weighing.

In February 1997 and 2000, we evaluated the degree to which nitrogen pools varied among the three microhabitat types. We collected $20 \mathrm{~g}$ of soil at a depth of $5 \mathrm{~cm}$ from randomly determined locations under each shrub and in the shrub-free areas. We then analysed $10 \mathrm{~g}$ of soil from each of these samples for ammonium $\left(\mathrm{NH}_{4}^{+}\right)$and nitrate $\left(\mathrm{NO}_{3}^{-}\right)$content using standard $\mathrm{KCl}$ procedures (Binkley \& Hart 1989; Binkley \& Vitousek 1989). The resulting extracts were frozen and later analysed at the University of California DANR Analytical Laboratory (Davis). We dried unextracted soil fractions at $60^{\circ} \mathrm{C}$ for $24 \mathrm{~h}$, re-weighed samples to determine soil moisture content, and adjusted nutrient values to control for differences in soil moisture. In March 2000, we also quantified mineralization rates by incubating soil in breathable polyethylene bags at room temperature for 30 days. The difference in nitrogen content between initial samples and those incubated for 1 month represented an estimate of net mineralization rates. 


\section{Spacing patterns of shrubs}

In spring 1998, we established $1018 \mathrm{~m} \times 18 \mathrm{~m}$ plots to analyse the intraspecific spacing patterns exhibited by Ericameria and Lupinus at our dune study site (five plots per species). Our focus was on intraspecific patterns rather than interspecific ones because the two species often occur in different areas of the dune: Ericameria is more abundant in the dune trough whereas Lupinus is more abundant on the slopes of dune ridges. For all plots, we measured the distance from each shrub to its nearest neighbour of the same species. To correct for edge effects (see Sinclair 1985; Krebs 1999), we used the true nearest neighbour, whether it was located inside or outside the plot. We also estimated the size of each shrub by taking the average of two diameters - its maximum diameter and the diameter perpendicular to the maximum. These values were used to assess the relationship between the combined size of neighbouring shrub pairs and the distance separating them.

\section{Statistical analyses}

We analysed our data using the JMP 7 statistical program (SAS Institute, Cary, NC, USA). We performed five separate two-way MANOVAs, with microhabitat type (under Lupinus, under Ericamer$i a$, and shrub-free areas) and block (24 in 1996, 17 in 1998, and 14 in 2000) as the grouping factors and the following groups of response variables: (a) Claytonia, Bromus and Vulpia cover and density in 1996; (b) species richness of grasses and forbs in 1998, (c) species richness and aboveground biomass of grasses and forbs in 2000; (d) pools of ammonium and nitrate in 1997; and (e) pools and mineralization of ammonium and nitrate in 2000. For all MANOVAs with significant microhabitat terms, we proceeded with "protected" two-way ANOVAs on each response variable using the same grouping factors. As discussed by Scheiner (2001), this approach is an effective method for addressing potential correlations among multiple dependent variables (see Alvarez \& Cushman 2002; Cushman et al. 2004; Cushman \& Gaffney 2010). Because there was no replication within block, we could not calculate microhabitat $\times$ block interaction terms in our MANOVA and ANOVA analyses. Data from 1996 on leaf litter were analysed with a two-way ANOVA (microhabitat and block as grouping factors) and those for moss cover were evaluated with a one-way ANOVA (microhabitat as grouping factor). We treated block as a random effect, arcsine square- root transformed all percentage data and log-transformed all other variables to homogenize variances. We performed Tukey-Kramer HSD multiple comparison tests $(\alpha=0.05)$ on all ANOVAs with significant microhabitat main effects. This test corrects for the number of pair-wise comparisons being made within an ANOVA.

We evaluated the dispersion pattern of Ericameria and Lupinus in our 10 plots using Clark \& Evans' (1954) nearest-neighbour index $(R)$, which ranges from 0 to 2.15 . Index values that do not depart significantly from 1 indicate a random distribution, whereas those significantly less than 1 indicate clumped or aggregated distributions, and values significantly more than 1 indicate uniform or regular distributions. We evaluated the statistical significance of all nearest-neighbour index values $(R)$ using the $\mathrm{z}$ transformation (see Clark \& Evans 1954 and Krebs 1999 for details). We also performed an ANCOVA to evaluate the relationship between combined size of neighbouring shrub pairs and the distance separating them, with shrub species as a grouping factor, combined diameter as a covariate, and distance separating neighbouring shrubs as the response variable.

\section{Results}

\section{Density and cover of individual plant species}

Results from a two-way MANOVA revealed that, collectively, cover and density of Claytonia, Bromus and Vulpia varied significantly among microhabitat types in $1996\left(F_{14,80}=36.84, P<0.0001\right)$. Subsequent protected ANOVAs showed that this result was due to significant responses in all six variables. As shown in Fig. 1, percent cover and density of Claytonia varied significantly among microhabitats $\quad\left(F_{2,46}=74.49, \quad P<0.0001 \quad\right.$ and $F_{2,46}=543.43, P<0.0001$, respectively), with multiple comparison tests showing that values were higher under each of the two shrubs than in the shrub-free area. The pattern for Bromus was similar $\left(F_{2,46}=23.47, P<0.0001\right.$ and $F_{2,46}=7.10$, $P=0.002$, respectively), with cover and density being significantly higher under shrubs than in shrub-free areas (Fig. 1). In contrast, cover and density of Vulpia was highest in shrub-free areas, followed by under Ericameria and then Lupinus (Fig. 1; $F_{2,46}=30.38, P<0.0001$ and $F_{2,46}=15.43$, $P<0.0001$, respectively). A third type of pattern was found for the mosses: percent cover again varied significantly among microhabitats $\left(F_{2,72}=10.19\right.$, 

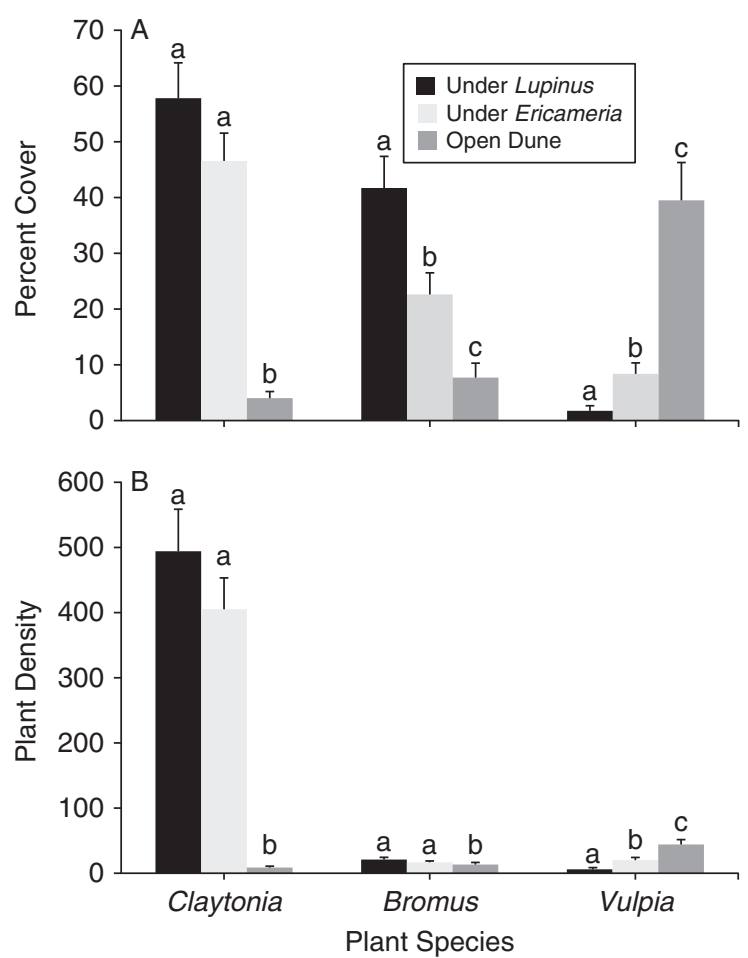

Fig. 1. Percent cover and density (mean $\pm 1 \mathrm{SE}$ ) of three herbaceous plant species across three microhabitat types (under Lupinus chamissonis, under Ericameria ericoides and open dune) in a coastal dune ecosystem. Letters above bars refer to results from multiple comparison tests.

$P<0.0001$ ), but was highest under Ericameria and equally low under Lupinus and in shrub-free areas (Fig. 2a).

\section{Plant species richness and aboveground biomass}

Results from our second and third MANOVAs indicated that, collectively, species richness and aboveground biomass of grasses and forbs varied significantly among microhabitat types in 1998 $\left(F_{4,62}=3.18, \quad P=0.019\right)$ and $2000 \quad\left(F_{8,46}=2.32\right.$, $P=0.035)$. However, subsequent ANOVAs revealed that the responses of grasses and forbs were very different. As shown in Fig. 3, species richness of grasses in 1998 and 2000 did not vary significantly among microhabitat types $\left(F_{2,32}=0.67, P=0.52\right.$ and $F_{2,26}=0.02, P=0.98$, respectively), and the same was true in 2000 for aboveground grass biomass $\left(F_{2,26}=1.85, P=0.18\right)$. In contrast, forb species richness varied significantly among microhabitat types in 1998 and $2000 \quad\left(F_{2,32}=6.17\right.$, $P=0.005$ and $F_{2,26}=4.62, P=0.019$, respectively) and a similar trend was evident for aboveground biomass in $2000\left(F_{2,26}=2.77, P=0.081\right)$. In all three
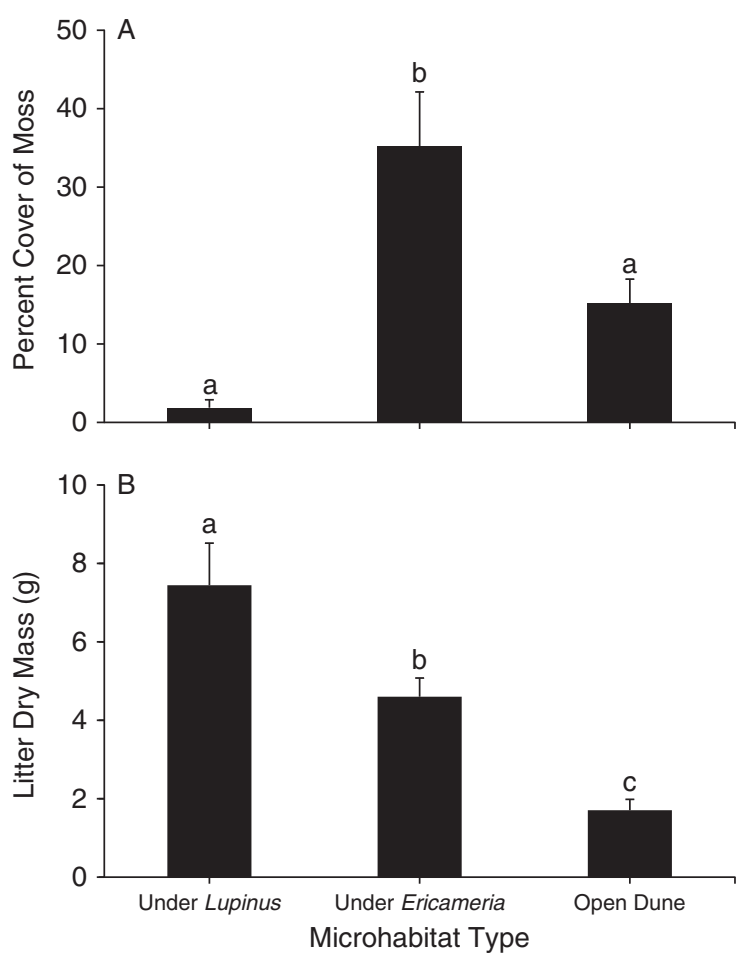

Fig. 2. Percent cover of three moss species and accumulating litter biomass (mean \pm 1 SE) across three microhabitat types (under Lupinus chamissonis, under Ericameria ericoides and open dune) in a coastal dune ecosystem. Letters above bars refer to results from multiple comparison tests.

cases, forb richness and biomass were highest in the open dune and equally low beneath the two shrub species (Fig. 3).

\section{Litter biomass and soil nitrogen}

In this dune ecosystem, microhabitats beneath shrub canopies were markedly different from the open dune in amount of plant litter and soil nitrogen. A two-way ANOVA indicated that the amount of accumulated plant litter in 1996 varied significantly among microhabitat types $\left(F_{2,46}=37.5\right.$, $P<0.0001$ ), with litter being highest beneath Lupinus, intermediate beneath Ericameria and least in shrub-free areas (Fig. 2b).

Results from our fourth and fifth MANOVAs indicated that, collectively, soil nitrogen pools in 1997, as well as nitrogen pools and mineralization rates in 2000, varied significantly among microhabitat types $\left(1997-F_{4,88}=7.15, P<0.0001 ; 2000-\right.$ $\left.F_{8,46}=8.43, P<0.0001\right)$. Further ANOVAs revealed that ammonium and nitrate pools varied significantly among microhabitat types in 1997 $\left(F_{2,46}=9.67, P=0.0003\right.$ and $F_{2,46}=5.15, P=0.01$, 

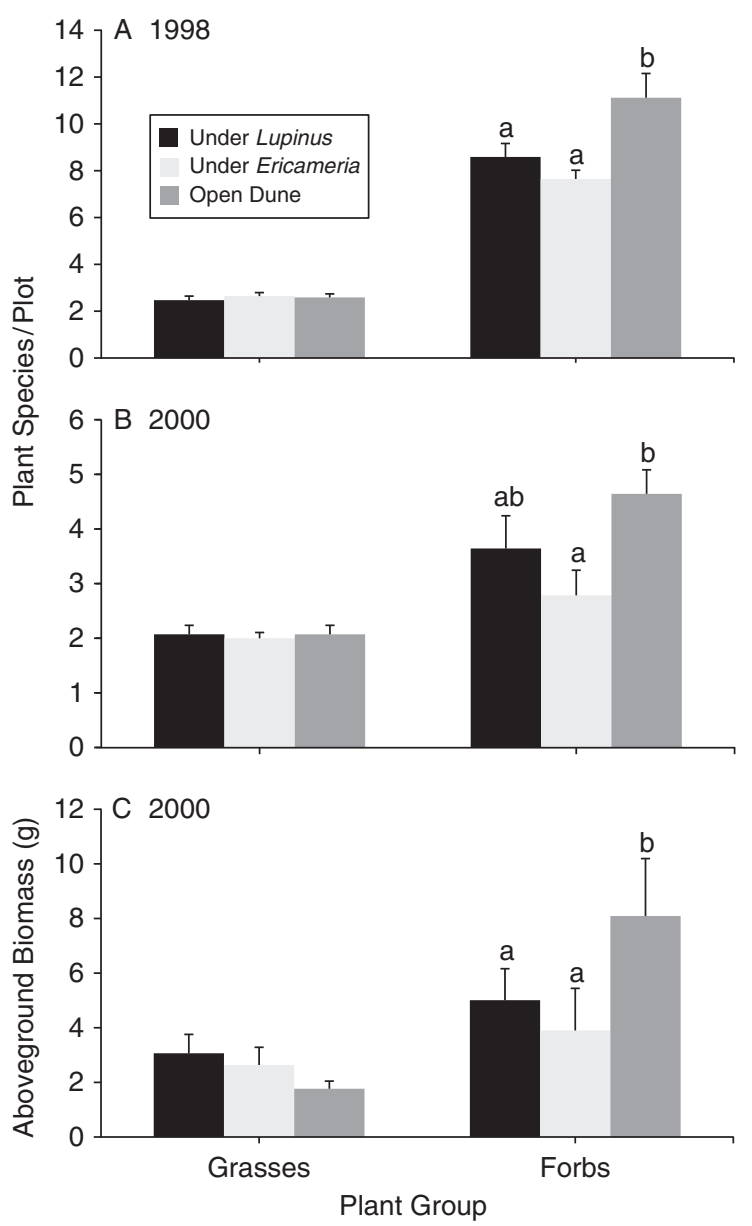

Fig. 3. Species richness in 2 years and aboveground dry biomass in 1 year for grasses and forbs (mean $\pm 1 \mathrm{SE}$ ) across three microhabitats (under Lupinus chamissonis, under Ericameria ericoides and open dune) in a coastal dune ecosystem. Letters above bars refer to results from multiple comparison tests.

respectively) and $2000\left(F_{2,26}=30.33, P<0.0001\right.$ and $F_{2,26}=7.07, P=0.004$, respectively). In both years, ammonium levels were equally large beneath the two shrub species and significantly lower in the shrubfree areas (Fig. 4a and b). The pattern for nitrate pools varied between years, with levels being significantly higher beneath Lupinus and equally low beneath Ericameria and shrub-free areas in 1997 (Fig. 4a) and equally large beneath the two shrubs and slightly lower in the open dune in 2000 (Fig. 4b). Rates of ammonium mineralization in 2000 did not vary among microhabitat types $\left(F_{2,26}=1.41\right.$, $P=0.262)$, whereas there were significant differences for nitrate $\left(F_{2,26}=13.78, P<0.0001\right.$ Fig. $\left.4 \mathrm{c}\right)$. Mineralization rates for nitrate were significantly higher beneath Lupinus, followed by Ericameria and then shrub-free areas.
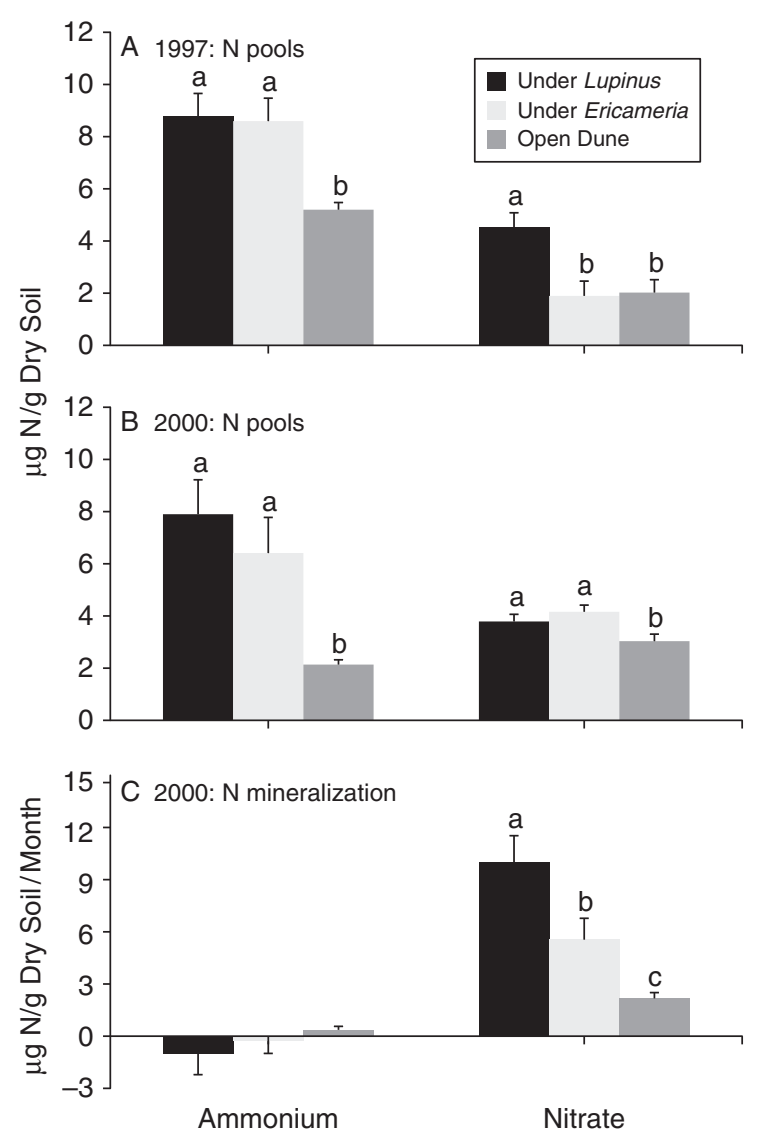

Fig. 4. Ammonium and nitrate pools as well as mineralization rates (mean $\pm 1 \mathrm{SE}$ ) across three microhabitat types (under Lupinus chamissonis, under Ericameria ericoides and open dune) in 1997 and 2000. Letters above bars refer to results from multiple comparison tests.

\section{Spacing patterns of shrubs}

Our dispersion analysis of Ericameria indicated that values of Clark \& Evans' (1954) nearest-neighbour index (R) were significantly above 1 in all cases, indicating a uniform spacing pattern (Table 1a). In contrast, the patterns for Lupinus were less consistent. In two plots, index values were significantly higher than 1 (indicating uniform spacing), whereas values were not significantly different from 1 (random spacing pattern) in the remaining three plots (Table $1 b$ ).

Linear regression analysis indicated that the combined size of neighbouring shrub pairs for each species was a good predictor of the distance separating them. The distance separating Lupinus pairs increased significantly with increased shrub size (Fig. 5a; $y=0.585+0.349 x, F_{1,217}=76.55, P<0.0001$, $R^{2}=0.261$ ). A similar pattern was also observed for Ericameria shrub pairs (Fig. 5b; $y=0.814+0.317 x$, $\left.F_{1,247}=137.4, \quad P<0.0001, R_{2}=0.357\right)$. Although 
Table 1. Intraspecific dispersion patterns exhibited by Ericameria ericoides (a) and Lupinus chamissonis (b) in a coastal dune ecosystem. Results from nearest-neighbour analyses are shown, with dispersion index values $(R)$ significantly more than 1.0 indicating over-dispersion (uniformity) and insignificant values indicating random dispersion. Standard error values are provided with mean nearest-neighbour distances (NNDs).

\begin{tabular}{|c|c|c|c|c|c|}
\hline Species & Plot & Density & Mean NND (m) & $R$ value & $P$ \\
\hline \multicolumn{6}{|c|}{ (a) Ericameria ericoides } \\
\hline & 1 & 0.21 & $1.44 \pm 0.07$ & 1.32 & $<0.001$ \\
\hline & 2 & 0.24 & $1.42 \pm 0.05$ & 1.40 & $<0.001$ \\
\hline & 3 & 0.17 & $1.65 \pm 0.06$ & 1.35 & $<0.001$ \\
\hline & 4 & 0.14 & $1.91 \pm 0.08$ & 1.44 & $<0.001$ \\
\hline & 5 & 0.11 & $1.78 \pm 0.12$ & 1.18 & $<0.050$ \\
\hline \multicolumn{6}{|c|}{ (b) Lupinus chamissonis } \\
\hline & 6 & 0.26 & $1.02 \pm 0.07$ & 1.05 & $>0.40$ \\
\hline & 7 & 0.30 & $1.01 \pm 0.06$ & 1.11 & $=0.05$ \\
\hline & 8 & 0.22 & $1.26 \pm 0.08$ & 1.18 & $<0.02$ \\
\hline & 9 & 0.12 & $1.45 \pm 0.18$ & 1.00 & $>0.70$ \\
\hline & 10 & 0.14 & $1.19 \pm 0.12$ & 0.90 & $>0.70$ \\
\hline
\end{tabular}

neighbouring Ericameria plants were spaced further apart than neighbouring Lupinus plants $\left(F_{1,464}=4.92, P=0.027\right)$, the two species did not exhibit significantly different slopes in the distancediameter regression $\left(F_{1,464}=0.44, P=0.508\right.$; see Fig. 5).

\section{Discussion}

In this paper, we present data suggesting that two dominant shrubs, Lupinus chamissonis and Ericameria ericoides, are important ecosystem engineers in a coastal hind dune in northern California, as they greatly alter the vegetation and soil nutrients found beneath their canopies. At the population level, our data suggest that shrubs had a facilitative effect (i.e. positive) on the cover and density of the native forb Claytonia perfoliata and the exotic grass Bromus diandrus (Fig. 1). In contrast, shrubs appeared to have negative effects on the cover and density of the exotic grass Vulpia bromoides (Fig. 1). The two shrub species differed in their influence on three native moss species, with cover being highest under Ericameria and equally low under Lupinus and in shrub-free areas (Fig. 2a). At the community level, both shrub species were associated with reduced species richness and aboveground biomass of forbs, while there was no pattern for grasses (Fig. 3). At the ecosystem level, more plant litter accumulated in areas beneath shrubs (Fig. 2b) and, presumably because of this, soils associated with both shrub species had higher

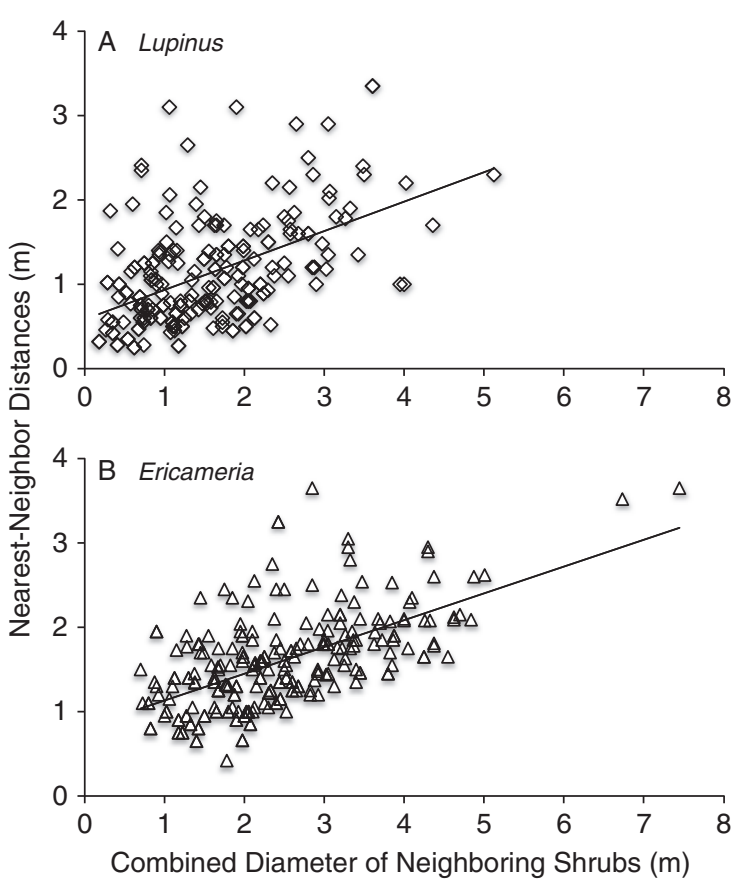

Fig. 5. Nearest-neighbour distances plotted as a function of the combined diameter of neighbouring (a) Lupinus chamissonis and (b) Ericameria ericoides shrubs.

pools of ammonium and, to a lesser degree, nitrate than the open dune (Fig. 4a and b). In addition, rates of nitrate mineralization were faster beneath the canopy of Lupinus, followed by Ericameria and then the open dune (Fig. 4c). Lastly, at a larger spatial scale, we found that these two shrub species and therefore their unique patterns of vegetation and soil nutrients - were often distributed uniformly throughout our dune site, with the distance separating neighbouring shrubs increasing as their combined sizes increased (Fig. 5).

Given that the data presented in the paper are non-experimental, we need to evaluate hypotheses for why the vegetative and soil characteristics beneath shrubs were so markedly different from those found in adjacent shrub-free areas. We hypothesize that shrubs themselves are directly and indirectly responsible for the patterns detected in our study, and believe that the literature strongly supports this conclusion. Shrubs are well known to create distinct physical environments beneath their canopies that, in turn, lead to pronounced changes in vegetation, litter and soil characteristics (see Callaway 1995; Pugnaire et al. 1996, 2004; Scholes \& Archer 1997; Holzapfel et al. 2006; Wright et al. 2006; Shachak et al. 2008). An alternative interpretation of our results is that shrubs were more likely to become established in patches with litter- and nitrogen-rich 
soils, and that the associated vegetation patterns were the result of such higher nutrient levels. For numerous reasons, this view seems extremely unlikely. First, our previous work (McNeil \& Cushman 2005; Lortie \& Cushman 2007) as well as that of Barbour et al. (1973) has shown that highnutrient patches do not occur commonly at this dune site, unless associated with established shrubs. Second, nitrogen levels in the soil under the canopies of young, newly established Lupinus and Ericameria plants were no different from those found in shrubfree areas (J. C. Waller and J. H. Cushman, unpublished data), and the reverse would have been expected if this alternative hypothesis were true. Thus, we are confident that Lupinus and Ericameria are the primary drivers of the biotic and abiotic patterns detected in our dune system.

Perennial plants commonly create "islands of fertility" beneath their canopies (Callaway 1995; Alpert \& Mooney 1996; Scholes \& Archer 1997; Reynolds et al. 1999; Pugnaire et al. 2004; Shachak et al. 2008), and our data strongly suggest that $\mathrm{Lu}$ pinus and Ericameria both have such effects. We hypothesize that higher litter quantity under shrubs was a major factor causing the increased nitrogen pools and mineralization rates. This probably occurred via two pathways: shrubs deposited leaf litter that accumulated beneath their canopies and shrubs also acted as litter traps, collecting diverse assortments of litter produced by adjacent plants in the community. We also hypothesize that variation in litter quality and quantity was responsible for the observed differences between the two shrub species in nitrate pools (Fig. 4a) and mineralization rates (Fig. 4c). In both cases, values were significantly higher under Lupinus than Ericameria. Presumably, these differences occurred in part because Lupinus is a nitrogen-fixer and thus produces nitrogen-rich litter (McNeil \& Cushman 2005; also see Bentley \& Johnson 1991; Maron \& Connors 1996; Pugnaire et al. 1996, 2004; Shumway 2000). Lupinus litter should decompose more rapidly than that of Ericameria because rates of litter decomposition are known to increase with nitrogen content (Aber \& Melillo 1991; McNeil \& Cushman 2005). In addition, Ericameria produces tougher leaves that probably contain more lignin, in addition to lower nitrogen levels, which further slows decomposition rates (Aber \& Melillo 1991). Litter quantity may be just as important as litter quality, and Lupinus deposits more leaf litter than Ericameria (Fig. 2b), probably because they produce larger leaves that have a shorter retention time. Thus, differences in leaf size, chemical composition and retention time all appear to be critical characteristics that explain the speciesspecific effects of shrubs on ecosystems.

We hypothesize that differences in light, water, leaf litter and soil nitrogen were the major drivers of the variation in percent cover and density for the herbaceous dominants in our system. Claytonia is a fast-growing, fleshy annual, and the moist, shady conditions under shrubs provide an ideal location for its growth and reproduction. For example, at our study site, Waller (1998) found that Claytonia was taller under shrubs then in shrub-free areas. The success of Bromus under shrub canopies, especially under Lupinus, is not surprising given that these patches have increased nitrogen levels (Fig. 4), which have been shown to promote its density and growth (Callaway et al. 1991; Maron \& Connors 1996). Our results for Vulpia suggest that this invader is less tolerant of shade and/or less effective at competing with other understorey species for the nutrients that abound beneath shrub canopies. The two shrub species appear to have dramatically different effects on the cover of mosses in our system (Fig. 2a), which are not readily explained by light and moisture levels (see Waller 1998). One possible explanation for the lower cover of mosses under Lupinus compared to Ericameria is that high nitrate pools and mineralization rates (Fig. 5) inhibited the success of mosses. Although this may be possible, Titus (2009) found that moss cover was higher under nitrogen-fixing species than in open areas in a nondune system. Another possibility is that the increased amounts of litter accumulating under Lupinus shrubs (Fig. 2b) adversely affected moss cover.

Grasses and forbs exhibited markedly different responses to shrubs in our dune system. Biomass and species richness of grasses were both unaffected by shrubs, whereas there was a negative effect on these variables for forbs (Fig. 3). At least for biomass, the absence of effects for grasses may have been due to contrasting responses of the two most dominant species, with density and cover of Bromus being higher under shrubs, and that for Vulpia being highest in shrub-free areas. In terms of forbs, increased nitrogen levels beneath shrubs might reduce their species richness by favouring rapidly growing forb species that are able to capitalize on these resources and competitively exclude slower-growing forb taxa (Maron \& Connors 1996; Jefferies \& Maron 1997; Collins et al. 1998). However, nitrogen availability by itself appears insufficient to explain our results, given that the richness reductions in other systems were usually associated with increased biomass production, which we did not find (Fig. 3c). 
A second factor that could explain our forb results is litter accumulation, which has been shown to suppress germination, growth and/or plant species richness (e.g. Knapp \& Seastedt 1986; Foster \& Gross 1998; Suding \& Goldberg 1999; Cavieres et al. 2007). Although this may occur in our system, we suspect the most important factor is reduced light levels under shrub canopies, which prevent forbs from capitalizing on the increased nitrogen availability. Offering support for this view is work by Maron \& Connors (1996) in a coastal prairie adjacent to our site, which demonstrated that increased nitrogen supplies under Lupinus arboreus had large effects on the plant community, but only after the shrubs died and light levels increased.

Interactions among neighbouring plants may influence the spatial distribution of shrubs in the landscape, and therefore the distribution of their effects on vegetation and soil characteristics. Two lines of evidence suggest that intraspecific competition among shrubs, particularly Ericameria, has been sufficiently strong in the past to influence spacing patterns at our site: shrubs often exhibited uniform spatial distributions (Table 1), and the distance separating neighbouring shrubs increased with increasing size of shrubs (Fig. 5). These data suggest that the intensity of competition may increase with increasing size of the adjacent individuals (see Phillips \& MacMahon 1981). However, regardless of whether competition is driving these spatial patterns, the distinctive vegetation and nitrogen availability associated with shrubs are distributed in a fairly orderly fashion throughout the dune landscape.

Factors that influence the abundance or size of shrubs in the landscape should have large impacts on this system, given that shrubs create discrete patches that differ markedly from the surrounding matrix. Two factors are especially important in our dune system. First, exclosure experiments have revealed that herbivory by black-tailed deer (Odocoileus hemionus columbianus) and black-tailed jackrabbits (Lepus californicus) reduced the size of Lupinus and Ericameria, respectively (Warner \& Cushman 2002; McNeil \& Cushman 2005; Huntzinger et al. 2008). Second, the abundance and size of both shrub species decreased along a welldocumented stress gradient that occurs along a 200-m stretch of dune at our site (Lortie \& Cushman 2007). Specifically, the size and abundance of both shrub species decreased at the more stressful end of the gradient - areas that experienced higher wind speeds, coarser soil, and lower soil moisture and nitrate levels. Thus, herbivory and environmental stress are two factors that reduce the influence of shrubs in our dune system (i.e. they reduce the amount of shrub-influenced dune in the landscape).

In conclusion, our data suggest that two shrub species serve as ecosystem engineers in a coastal dune system, having influences at multiple levels of biological organization. The two shrubs frequently varied in their effects on plant populations, communities and ecosystems, thus highlighting the species-specific impacts of different ecosystem engineers. Shrubs had a complex mixture of positive and negative effects on individual understorey plant species and depressed species richness and biomass of herbaceous dicots. Our data also support the hypothesis that intraspecific competition has influenced the spatial distributions of these shrubs, and thus altered the distribution of their effects throughout the landscape. Collectively, these finding not only contribute to the growing literature on the importance of shrubs in ecological systems but also demonstrate the complexity and variability of these impacts.

Acknowledgements. We are grateful to Peter Alpert, Caroline Christian, Andrew Kleinhesselink, Christopher Lortie, Nathan Rank, Vanessa Rashbrook, Anna Sears Don Strong and two anonymous reviewers for their comments on drafts of this manuscript. Rebecca Anderson, Morgan Doran, Sarah Dunbar, Sean McNeil, Jennifer Michaud, Anna Sears, Mark Smith and Peter Warner provided invaluable assistance in the field. Discussions with John Maron, Caroline Christian, Andrew Kleinhesselink and Christopher Lortie were especially helpful. Student projects by Denise Cadman, Sarah Dunbar, Dino Garcia Rossi, Sean McNeil, James Welch and Mark Smith paved the way for this research. This research was generously supported by grants from Sonoma State University, National Geographic Society, Bodega Field Conference and the National Science Foundation (DEB9981663).

\section{References}

Aber, J.D. \& Melillo, J.M. 1991. Terrestrial ecosystems. Saunders Publishing, Philadelphia, US.

Agra, H. \& Ne'eman, G. 2009. Woody species as landscape modulators: their effect on the herbaceous plants in the Mediterranean maquis. Plant Ecology 205: 165-177.

Aguiar, M.R. \& Sala, O.E. 1994. Competition, facilitation, seed distribution and the origin of patches in a Patagonian steppe. Oikos 70: 26-34.

Alpert, P. \& Mooney, H.A. 1996. Resource heterogeneity generated by shrubs and topography on sand dunes. Vegetatio 122: 83-93. 
Alvarez, M.E. \& Cushman, J.H. 2002. Community level consequences of a plant invasion: effects on three habitats in coastal California. Ecological Applications 12: 1434-1444.

Armas, C. \& Pugnaire, F.I. 2005. Plant interactions govern population dynamics in a semiarid plant community. Journal of Ecology 93: 978-989.

Badano, E.I., Jones, C.G., Cavieres, L.A. \& Wright, J.P. 2006. Assessing impacts of ecosystem engineers on community organization: a general approach illustrated by effects of a high-Andean cushion plant. Oikos 115: 369-385.

Barbour, M.G., Craig, R.B., Drysdale, F.R. \& Ghiselin, M.T. 1973. Coastal ecology: bodega head. University of California Press, Berkeley, CA, US.

Bartholemew, B. 1970. Bare zone between California shrub and grassland communities: the role of animals. Science 170: 1210-1212.

Bentley, B.L. \& Johnson, N.D. 1991. Plants as food for herbivores: the roles of nitrogen fixation and carbon dioxide enrichment. In: Price, P.W., Lewinsohn, T.M., Fernandes, G.W. \& Benson, W.W. (eds). Plant-animal interactions: evolutionary ecology in tropical and temperate regions. pp. 257-272. Wiley, New York, NY, US.

Binkley, D. \& Hart, S.C. 1989. The components of nitrogen availability assessments in forest soils. Advances in Soil Science 10: 57-112.

Binkley, D. \& Vitousek, P. 1989. Soil nutrient availability. In: Pearcy, R.W., Ehleringer, J., Mooney, H.A. \& Rundel, R.W. (eds.) Plant physiological ecology: field methods and instrumentation. pp. 75-96. Chapman \& Hall, London, UK.

Callaway, R.M. 1992. Effect of shrubs on recruitment of Quercus douglasii and Quercus lobata in California. Ecology 73: 2118-2128.

Callaway, R.M. 1995. Positive interactions among plants. Botanical Review 61: 306-349.

Callaway, R.M. \& Walker, L.R. 1997. Competition and facilitation: a synthetic approach to interactions in plant communities. Ecology 78: 1958-1965.

Callaway, R.M., Nadkarni, N.M. \& Mahall, B.E. 1991. Facilitation and interference of Quercus douglasii on understory productivity in central California. Ecology 72: 1484-1499.

Cavieres, L.A., Chacon, P., Penaloza, A., MolinaMontenegro, M. \& Arroyo, M.T.K. 2007. Leaf litter of Kageneckia angustifolia D. Don (Rosaceae) inhibits seed germination in sclerophyllous montane woodlands of central Chile. Plant Ecology 190: 13-22.

Clark, P.J. \& Evans, F.C. 1954. Distance to nearest neighbor as a measure of spatial relationships in populations. Ecology 35: 445-453.

Collins, S.L., Knapp, A.K., Briggs, J.M., Blair, J.M. \& Steinauer, E.M. 1998. Modulation of diversity by grazing and mowing in native tallgrass prairie. Science 280: 745-747.

Cushman, J.H. \& Gaffney, K.A. 2010. Impacts of exotic clonal plants on riparian communities in northern
California. Biological Invasions doi: 10.1007/s10530009-9682-2.

Cushman, J.H., Tierney, T.A. \& Hinds, J.M. 2004. Variable effects of feral pig disturbances on native and exotic plants in a California grassland. Ecological Applications 14: 1746-1756.

Day, T.A. \& Wright, R.G. 1989. Positive plant spatial association with Eriogonum ovalifolium in primary succession on cinder cones: seed-trapping nurse plants. Vegetatio 70: 37-45.

Flores, J. \& Jurado, E. 2003. Are nurse-protégé interactions more common among plants from arid environments? Journal of Vegetation Science 14: 911916.

Foster, B.L. \& Gross, K.L. 1998. Species richness in a successional grassland: effects of nitrogen enrichment and plant litter. Ecology 79: 2593-2602.

Hamback, P.A., Agren, J. \& Ericson, L. 2000. Associational resistance: insect damage to purple loosestrife reduced in thickets of sweet gale. Ecology 81: 1784-1794.

Hickman, J.C. (ed.). 1993. The Jepson manual: higher plants of California. University of California Press, Berkeley, CA, US.

Holzapfel, C., Tielborger, K., Parag, H.A., Kigel, J. \& Sternberg, M. 2006. Annual plant-shrub interactions along an aridity gradient. Basic and Applied Ecology 7: 268-279.

Hunter, A.F. \& Aarssen, L.W. 1988. Plants helping plants. BioScience 38: 34-40.

Huntzinger, M., Karban, R. \& Cushman, J.H. 2008. Negative effects of vertebrate herbivores on invertebrates in a coastal dune community. Ecology 89: 1972-1980.

Jaksic, R.M. \& Fuentes, E.R. 1980. Why are native herbs in the Chilean matorral more abundant beneath bushes: microclimate or grazing? Journal of Ecology 68: 665-669.

Jefferies, R.L. \& Maron, J.L. 1997. The embarrassment of riches: atmospheric deposition of nitrogen and community and ecosystem processes. Trends in Ecology and Evolution 12: 74-78.

Jones, C.G., Lawton, J.H. \& Shachak, M. 1994. Organisms as ecosystem engineers. Oikos 69: 373-386.

Jones, C.G., Lawton, J.H. \& Shachak, M. 1997. Positive and negative effects of organisms as physical ecosystem engineers. Ecology 78: 1946-1957.

Knapp, A.K. \& Seastedt, T.R. 1986. Detritus accumulation limits productivity of tallgrass prairie. BioScience 36: 662-668.

Krebs, C.J. 1999. Ecological methodology. Addison Wesley Longhorn, New York, NY, US.

King, E.G. 2008. Facilitative effects of Aloe secundiflora shrubs in degraded semi-arid rangelands in Kenya. Journal of Arid Lands 72: 358-369.

Lortie, C.J. \& Cushman, J.H. 2007. Effects of a directional abiotic gradient on plant community dynamics and invasion in a coastal dune system. Journal of Ecology 95: 468-481. 
Mahall, B.E., Parker, V.T. \& Fonteyn, P.J. 1981. Growth and photosynthetic irradiance responses of Avena fatua L. and Bromus diandrus Roth. and their ecological significance in California savannas. Photosynthetica 15: 5-15.

Maron, J.L. \& Connors, P.G. 1996. A native nitrogenfixing shrub facilitates weed invasion. Oecologia 22: 302-312.

McAuliffe, J.R. 1986. Herbivore-limited establishment of a Sonoran Desert tree: Cercidium microphyllum. Ecology 67: 276-280.

McNeil, S.G. \& Cushman, J.H. 2005. Indirect effects of deer herbivory on local nitrogen availability in a coastal dune ecosystem. Oikos 110: 124-132.

Muller, C.H. \& del Moral, R. 1966. Soil toxicity induced by terpenes from Salvia leucophylla. Bulletin of the Torrey Botanical Club 93: 130-137.

Phillips, D.L. \& MacMahon, J.A. 1981. Competition and spacing pattern in desert shrubs. Journal of Ecology 69: 97-115.

Pugnaire, F.I., Haase, P., Puigdefabregas, J., Cueto, M., Clark, S.C. \& Incoll, L.D. 1996. Facilitation and succession under the canopy of a leguminous shrub, Retama spaerocarpa, in a semi-arid environment in south-east Spain. Oikos 76: 455-464.

Pugnaire, F.I., Armas, C. \& Valladares, F. 2004. Soil as a mediator in plant-plant interactions in a semi-arid community. Journal of Vegetation Science 15: 85-92.

Reynolds, J.F., Virginia, R.A., Kemp, P.R., De Soyza, A.G. \& Tremmel, D.C. 1999. Impact of drought on desert shrubs: effects of seasonality and degree of resource island development. Ecological Monographs 69: 69-106.

Rice, E.L. 1984. Allelopathy. 2nd ed. Academic Press, New York, NY, US.

Scheiner, S.M. 2001. MANOVA: multiple response variables and multispecies interactions. In: Scheiner, S.M. \& Gurevitch, J. (eds.) Design and analysis of ecological experiments. pp. 99-115. Chapman \& Hall, New York, NY, US.

Scholes, R.J. \& Archer, S.R. 1997. Tree-grass interactions in savannas. Annual Review of Ecology and Systematics 28: $517-544$.

Shachak, M., Boeken, B., Groner, E., Kadmon, R., Lubin, Y., Meron, E., Ne'Eman, G., Perevolotsky,
A., Shkedy, Y. \& Ungar, E.D. 2008. Woody species as landscape modulators and their effects on biodiversity patterns. BioScience 58: 209-221.

Shumway, S.W. 2000. Facilitative effects of a sand dune shrub on species growing beneath the shrub canopy. Oecologia 124: 138-148.

Sinclair, D. 1985. On tests of spatial randomness using mean nearest neighbor distance. Ecology 66: 1084-1085.

Suding, K.N. \& Goldberg, D.E. 1999. Variation in the effects of vegetation and litter on recruitment across productivity gradients. Journal of Ecology 87: 436-449.

Tirado, R. \& Pugnaire, F.I. 2003. Shrub spatial aggregation and consequences for reproductive success. Oecologa 136: 296-301.

Titus, J.H. 2009. Nitrogen fixers Alnus and Lupinus influence soil characteristics but not colonization of by later successional species in primary succession on Mount St. Helens. Plant Ecology 203: 289-301.

Uesaka, S. \& Tsuyuzaki, S. 2004. Differential establishment and survival of species in deciduous and evergreen shrub patches and on bare ground, Mt. Koma, Hokkaido, Japan. Plant Ecology 175: 165-177.

Waller, J.C. 1998. Shrubs as structuring agents in coastal dune ecosystems: positive and negative effects on herbaceous plant assemblages. Masters thesis, Sonoma State University, CA, US.

Warner, P.J. \& Cushman, J.H. 2002. Influence of herbivores on a perennial plant: variation with life history stage and herbivore species. Oecologia 132: 77-85.

Williamson, G.B. 1990. Allelopathy, Koch's postulates, and the neck riddle. In: Grace, J.B. \& Tilman, D. (eds.) Perspectives on plant competition. pp. 143-162. Academic Press, New York, NY, US.

Wright, J.P. \& Jones, C. 2004. Predicting effects of ecosystem engineers on patch-scale richness from primary productivity. Ecology 85: 2071-2081.

Wright, J.P., Jones, C.G., Boeken, B. \& Shachak, M. 2006. Predictability of ecosystem engineering effects on species richness across environmental variability and spatial scales. Journal of Ecology 94: 815-824.

Received 22 February 2010; Accepted 23 April 2010. Co-ordinating Editor: Dr. Beverly Collins. 